\title{
Evaluate the thermal performance of the dryer using a perforated wall furnace-heat exchanger for drying
}

\author{
Ida Bagus Alit and I Gede Bawa Susana* \\ Department of Mechanical Engineering, Faculty of Engineering, University of Mataram, Jl. Majapahit No. 62 Mataram- \\ Nusa Tenggara Barat 83125, Indonesia.
}

World Journal of Advanced Engineering Technology and Sciences, 2021, 02(02), 084-090

Publication history: Received on 24 April 2021; revised on 28 May 2021; accepted on 30 May 2021

Article DOI: https://doi.org/10.30574/wjaets.2021.2.2.0044

\begin{abstract}
The use of heat exchangers for the process of energy conversion from rice husks to thermal as an alternative to replacing sun drying. Drying with rice husk energy and heat exchanger does not depend on the weather. To determine the effectiveness of this dryer, a thermal evaluation was carried out on the heat exchanger and drying chamber with a sample of $4 \mathrm{~kg}$ of shelled corn. The test results showed an increase in the drying temperature of $112.31 \%$. The increase occurred from an average environmental temperature of $30.30^{\circ} \mathrm{C}$ to an average drying room temperature of $64.33^{\circ} \mathrm{C}$. The temperature increased significantly by $34.03^{\circ} \mathrm{C}$. This increase in temperature is a result of the use of a black steel pipe heat exchanger, rice husks, and the number of holes in the furnace wall that function as air circulation to help the process of burning rice husks. The distribution of the average temperature on each shelf in the drying room is rack 1 (Ts1) $76.79^{\circ} \mathrm{C}$, shelf 2 (Ts2) $65.24^{\circ} \mathrm{C}$, shelf 3 (Ts3) $59.77^{\circ} \mathrm{C}$, and shelf 4 (Ts4) $55.52^{\circ} \mathrm{C}$.
\end{abstract}

Keywords: Heat Exchanger; Rice Husk; Temperature

\section{Introduction}

Drying is one way to preserve post-harvest foodstuffs. The Utilizing of the sun in the drying process is the easiest and cheapest way. This is due to the abundance of sunshine throughout the year in Indonesia, especially the island of Lombok. Sun drying is done by drying foodstuffs in an open area. This model affects the less hygienic results of drying products due to exposure to dust or other impurities. In addition, when the weather is cloudy or rainy it will hamper the drying process. To anticipate this, an indirect drying method was developed using biomass energy and a heat exchanger.

The heat exchanger is used to heat the environmental air that will be used for the drying process of foodstuffs. Heat exchanger as a tool for implementing heat transfer between two fluids that are separated by a wall and have different temperatures [1]. The heat exchanger design is adapted to the needs of the dryer and the use of an energy source. Coconut coir energy for the drying process of fish using a heat exchanger with aligned tube bundles can produce an average drying temperature of $41.30^{\circ} \mathrm{C}$ [2]. The heat exchanger is located separately from the coconut coir furnace with hot smoke flowing in the pipes and environmental air flowing outside the pipes. Types of fluid flow in heat exchangers include parallel flow, counterflow, and crossflow. The temperature distribution in the no-load drying chamber is the lowest $36.3^{\circ} \mathrm{C}$ and the highest $66.7^{\circ} \mathrm{C}$ using a heat exchanger with a crossflow type and wood biomass energy source [3]. The use of a biomass dryer with a heat exchanger has positive results for increasing the productivity of the dried product. This can be seen based on changes in the rate of water content that occur in the drying process. To reduce the moisture content of maize from $19 \%$ to $12 \%$, it takes 62 minutes and 47 minutes, respectively, for air velocities of $2 \mathrm{~m} / \mathrm{s}$

\footnotetext{
${ }^{*}$ Corresponding author: I Gede Bawa Susana

Department of Mechanical Engineering, Faculty of Engineering, University of Mataram, Jl. Majapahit No. 62 Mataram-Nusa Tenggara Barat 83125, Indonesia.
} 
and $3 \mathrm{~m} / \mathrm{s}$ [4]. The use of heat exchangers aims to avoid contamination of biomass combustion smoke on the dried products. The indirect drying process using a heat exchanger and biomass provides advantages over solar drying. The temperature when drying the product directly in the sun is less than optimal. This has an impact on post-harvest losses. Unsuitable drying facilities in some developing countries cause post-harvest losses to the agricultural sector [5]. Drying in the sun has the effect of low quality and no added value as the product is dusty and hard [6]. Drying by dry in the sun can damage sensory and nutritional properties such as vegetables and fruits due to the heat sensitivity of these products [7]. The product structure damaged by sun-drying results in poor quality. This is based on evaluations carried out through physical parameters such as the distribution of pore size, volume, porosity, and texture [8]. As a substitute for the sun as a source of energy in drying, biomass can be used, one of which is rice husks.

Rice husks are effective as an energy source through an energy conversion process using heat exchangers. A heat exchanger is added to the furnace to facilitate the conversion of biomass into thermal energy. Rice husks are abundant in Indonesia related to rice as a staple food. Rice husk is a byproduct of rice production which has the potential to be used as sustainable energy. Rice husks meet the requirements for use as an energy source. This is because rice husks have a high cellulose composition reaching 50\% which results in stable and even combustion and a heating value of 11 $15.3 \mathrm{MJ} / \mathrm{kg}[9,10]$. Rice husks produce a maximum temperature of $556.5^{\circ} \mathrm{C}$ based on the results of the combustion test on the stove and the efficiency reaches $99.2 \%$ of the test results on the rectangular fluidized bed combustor [11, 12]. The heat generated from burning rice husks in the furnace will affect the temperature of the fluid in the heat exchanger pipes. The air supply is needed for the process of burning rice husks in the furnace. This affects the drying chamber temperature. This temperature is influenced by the temperature of the heat exchanger pipe. While the temperature of the heat exchanger pipe is influenced by the burning process of rice husks in the furnace [13]. The characteristic of burning rice husks is that the combustion process starts from the bottom of the stove and spreads upwards until the rice husks are completely burned. In addition, the farther the burning of the rice husks from the heat exchanger pipe, the lower the pipe temperature [14].

The high production of rice husks on the island of Lombok has the potential to be used as a source of energy for drying post-harvest agricultural products. Based on 2019 data, West Nusa Tenggara has the potential for rice husks of $533,150.80$ tons, and specifically Lombok Island of 269,420.20 tons, it is estimated that the energy produced can reach a power capacity of 60-65 MW $[15,16]$. Rice husks are effectively utilized as a source of renewable energy, namely by increasing property and logistics factors [17]. To optimize the energy use of rice husks, it is carried out through heat exchangers and furnaces. The process of transferring heat into the drying chamber is facilitated by a heat exchanger. The use of this dryer optimizes smallholder scale drying and is an alternative to overcast or rainy weather.

\section{Material and methods}

The research was conducted to find the distribution of heat in the drying chamber and heat exchanger. This is done by measuring the ambient temperature, the temperature in and out of the heat exchanger pipe, and the temperature distribution on each shelf in the drying chamber. The drying chamber consists of 4 shelves with dimensions of $600 \mathrm{~mm}$ x $536 \mathrm{~mm}$ x $536 \mathrm{~mm}$. The drying chamber is made of aluminum and is isolated using rubber with a thickness of $3 \mathrm{~mm}$. The drying chamber is equipped with an exhaust fan with a constant speed of $2 \mathrm{~m} / \mathrm{s}$. The furnace for burning rice husks has dimensions of $800 \mathrm{~mm}$ x $500 \mathrm{~mm}$ x $500 \mathrm{~mm}$. To help the combustion process, the furnace walls are equipped with air circulation holes with a total of 360 holes. The design of the furnace with holes in the walls is shown in Figure 1 and the research schematic is shown in Figure 2.

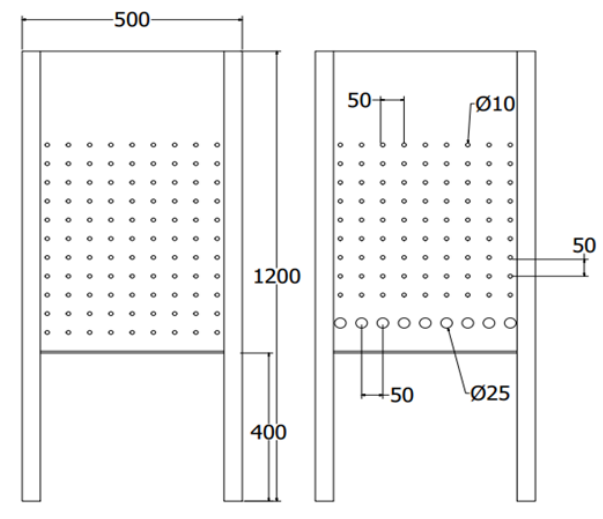

Figure 1 Schematic of a rice husk burning furnace with a hole in the wall 


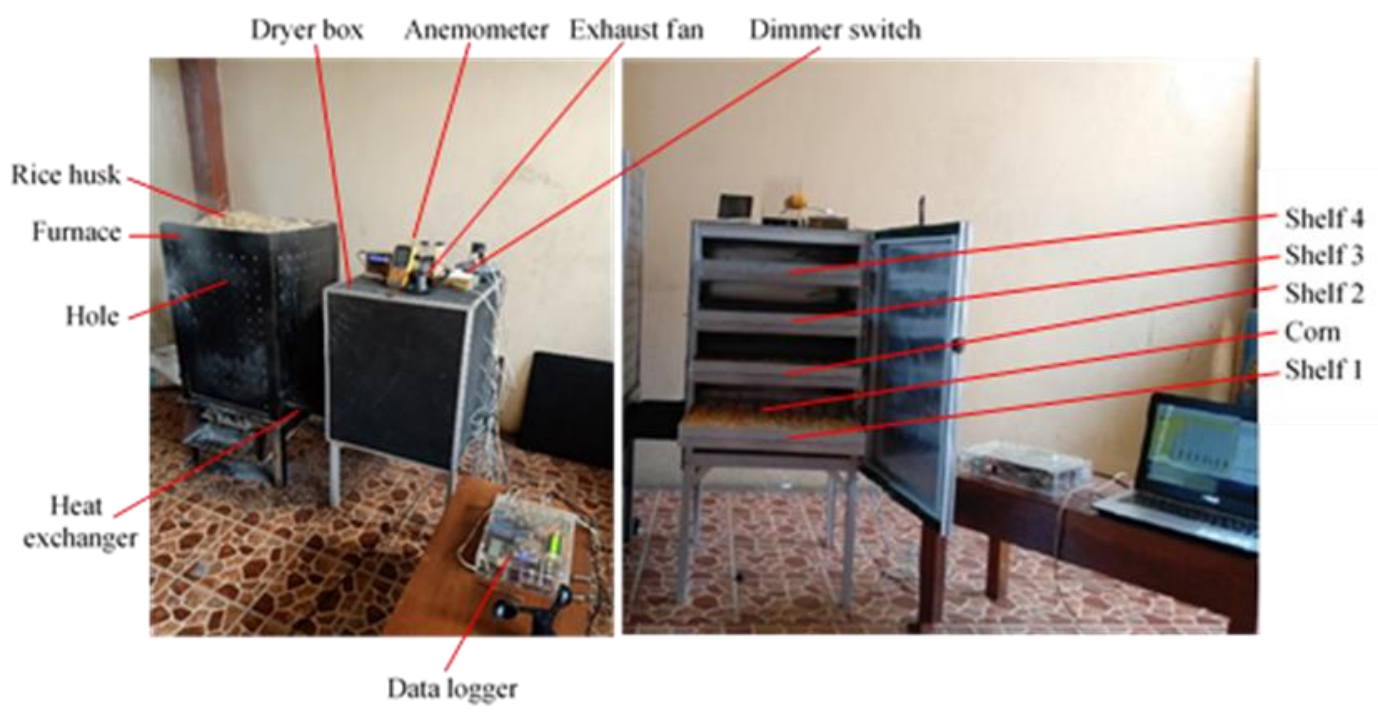

Figure 2 Research schematic

The furnace is equipped with a heat exchanger for the conversion of biomass energy into thermal energy. The heat exchanger consists of pipes arranged parallel to one pass airflow. The number of pipes is 9 with a length and diameter of $1 \mathrm{~m}$ and $1 \mathrm{inch}$, respectively. The post-harvest agricultural product used as the research sample was $4 \mathrm{~kg}$ shelled corn. The initial moisture content of corn was determined to be $19 \%$ by heating in the oven for 3.5 hours at a temperature of $105^{\circ} \mathrm{C}$. This mass of corn is evenly distributed on each shelf in the drying chamber. The main energy source for the furnace is rice husks. Tests are carried out to evaluate the distribution of heat on each shelf in the drying chamber. Measuring instruments used include stopwatches, digital scales, data loggers, anemometers, moisture meters, and type K thermocouples.

\section{Results and discussion}

The test results of the drying process on shelled corn samples were carried out for 250 minutes. The result of the furnace design can accommodate $20 \mathrm{~kg}$ of rice husk. The test was carried out with a fixed mass, namely that there was no addition of rice husks to the furnace. The results of the conversion of rice husks to thermal results in a ratio of ambient temperature (Ta) to the exit temperature of the heat exchanger pipes (Thx) as shown in Figure 3.

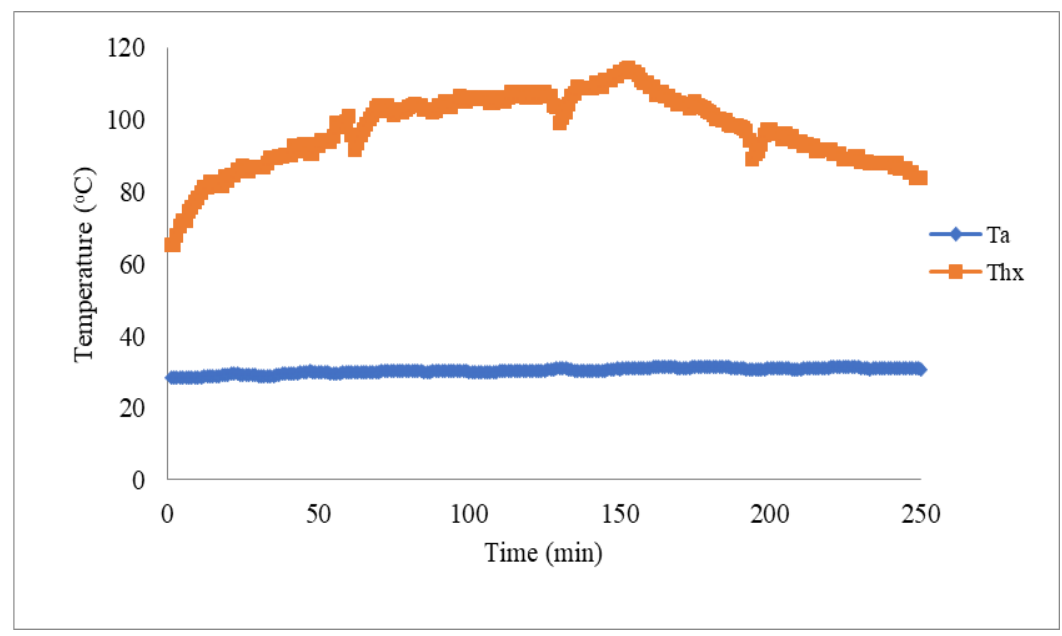

Figure 3 Comparison of ambient temperature (Ta) with heat exchanger (Thx)

The average ambient temperature (Ta) is $30.30^{\circ} \mathrm{C}$ with a range of $28.23-31.3^{\circ} \mathrm{C}$. While the average exit temperature of the heat exchanger pipes (Thx) resulting from the energy conversion of rice husks is $97.08^{\circ} \mathrm{C}$ with a range of 65.06 $114.32^{\circ} \mathrm{C}$. Utilization of rice husk energy with a heat exchanger added to the furnace can increase the temperature by 
$220.4 \%$. The increase in temperature as a result of the cellulose composition in rice husks is quite high by 50\% [9] and the thermal conductivity is quite high in the black pipe. The heat transfer rate is determined by thermal conductivity [18]. The exit temperature of the heat exchanger pipes (Thx) is the inlet temperature of the drying room for the drying process. The temperature distribution for each shelf in the drying chamber used to dry the corn is shown in Figure 4.

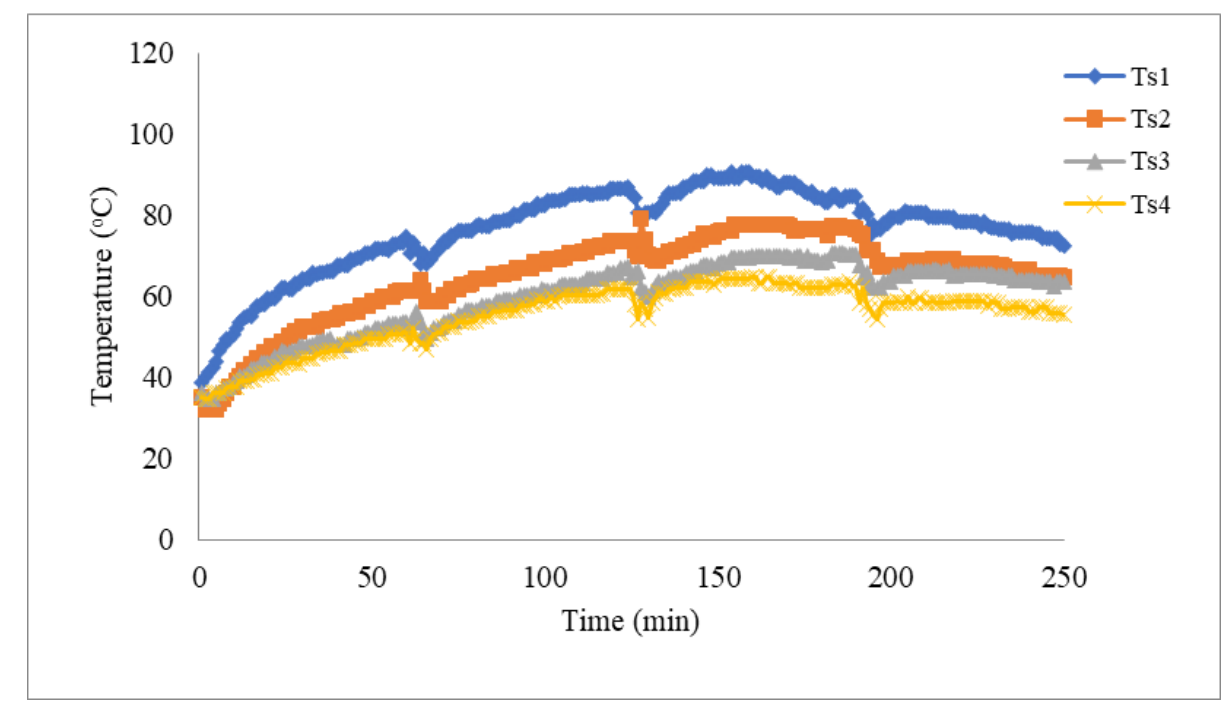

Figure 4 Temperature distribution on each shelf in the drying chamber

Corn drying temperature has different values on each shelf in the drying chamber. The average temperature on shelf 1 (Ts1), shelf 2 (Ts2), shelf 3 (Ts3), and shelf 4 (Ts4) respectively $76.79{ }^{\circ} \mathrm{C}$ with a range of $39.02-90.72^{\circ} \mathrm{C} ; 65.24{ }^{\circ} \mathrm{C}$ with a range of $32.21-79.35^{\circ} \mathrm{C} ; 59.77^{\circ} \mathrm{C}$ with a range of $34.88-70.77{ }^{\circ} \mathrm{C}$; and $55.52^{\circ} \mathrm{C}$ with a range of $34.86-64.75^{\circ} \mathrm{C}$. The highest temperature occurs on shelf 1 . This is due to the location of rack 1 in the drying room closest to the heat source or the temperature of the heat exchanger pipe. The lowest temperature occurs on shelf 4 because shelf 4 is farthest from the heat source. The temperature drop on shelf 4 is also caused by the heat that is first absorbed by the dried corn on the shelf below. The highest drying temperature occurs on the shelf near the heating source because the product is directly heated. The distribution of different temperatures in the drying chamber as shown in Figure 4 affects the change in mass of corn on each shelf. The temperature change is directly proportional to the change in the result of the drying mass of corn. This can be seen in Figure 5. The initial mass of maize is $4 \mathrm{~kg}$ which is distributed evenly, namely $1 \mathrm{~kg}$ on each shelf. After undergoing the drying process as shown in Figure 4, the final mass of corn is different for each shelf in the drying chamber.

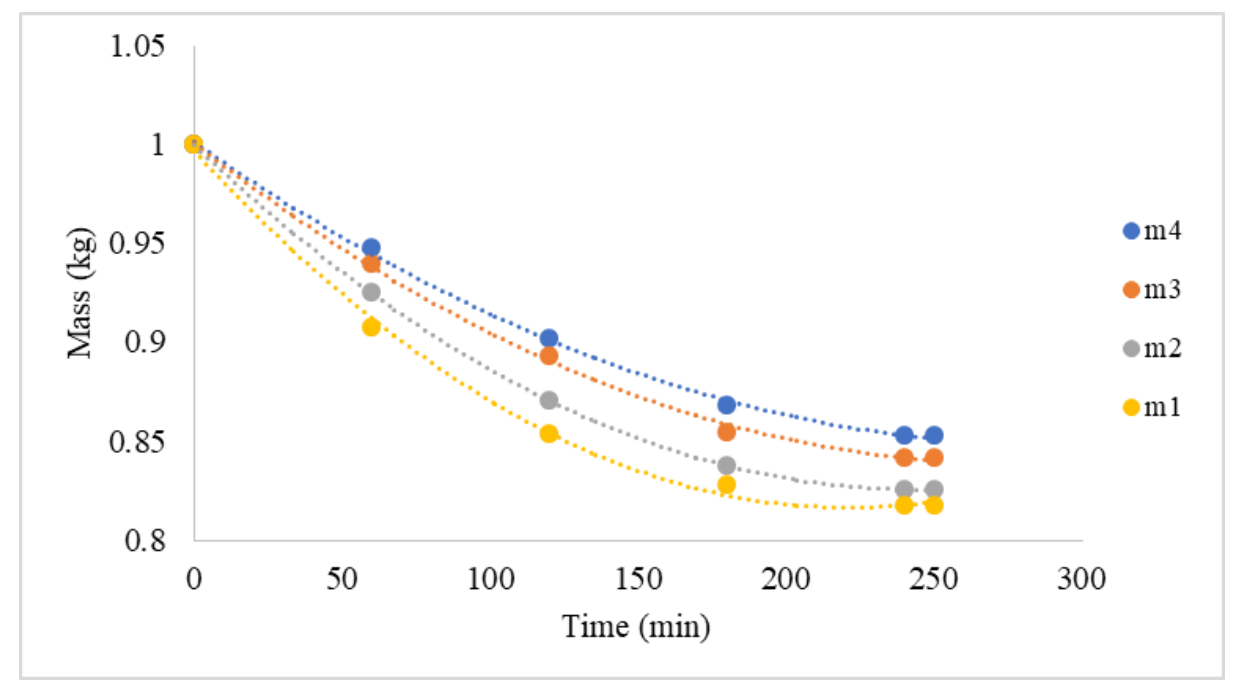

Figure 5 The mass distribution of corn on each shelf in the drying chamber

The highest change in corn mass occurred on shelf 1 (m1) and the lowest occurred on shelf 4 (m4). On shelf 1 (m1), shelf $2(\mathrm{~m} 2)$, shelf $3(\mathrm{~m} 3)$, and shelf $4(\mathrm{~m} 4)$, respectively, the decrease in corn mass occurred, $18.2 \%$ from $1 \mathrm{~kg}$ to 0.818 
$\mathrm{kg} ; 17.4 \%$, from $1 \mathrm{~kg}$ to $0.826 \mathrm{~kg} ; 15.8 \%$, from $1 \mathrm{~kg}$ to $0.842 \mathrm{~kg}$; and $14.7 \%$, from $1 \mathrm{~kg}$ to $0.853 \mathrm{~kg}$. This follows the phenomenon of different temperature changes for each shelf. The higher the drying temperature is followed by the higher the decrease in corn mass. Testing a sample of $4 \mathrm{~kg}$ of corn for 250 minutes carried out in the drying room resulted in a high residual drying temperature. This residual temperature is the temperature out of the drying chamber. This is as shown in Figure 6. The average temperature out of the drying room (To) is $54.33^{\circ} \mathrm{C}$ with a range of $34.05-$ $64.53^{\circ} \mathrm{C}$. Meanwhile, the average drying temperature of corn in the drying chamber (Ts, av) is $64.33^{\circ} \mathrm{C}$ with a range of $35.63-75.68^{\circ} \mathrm{C}$.

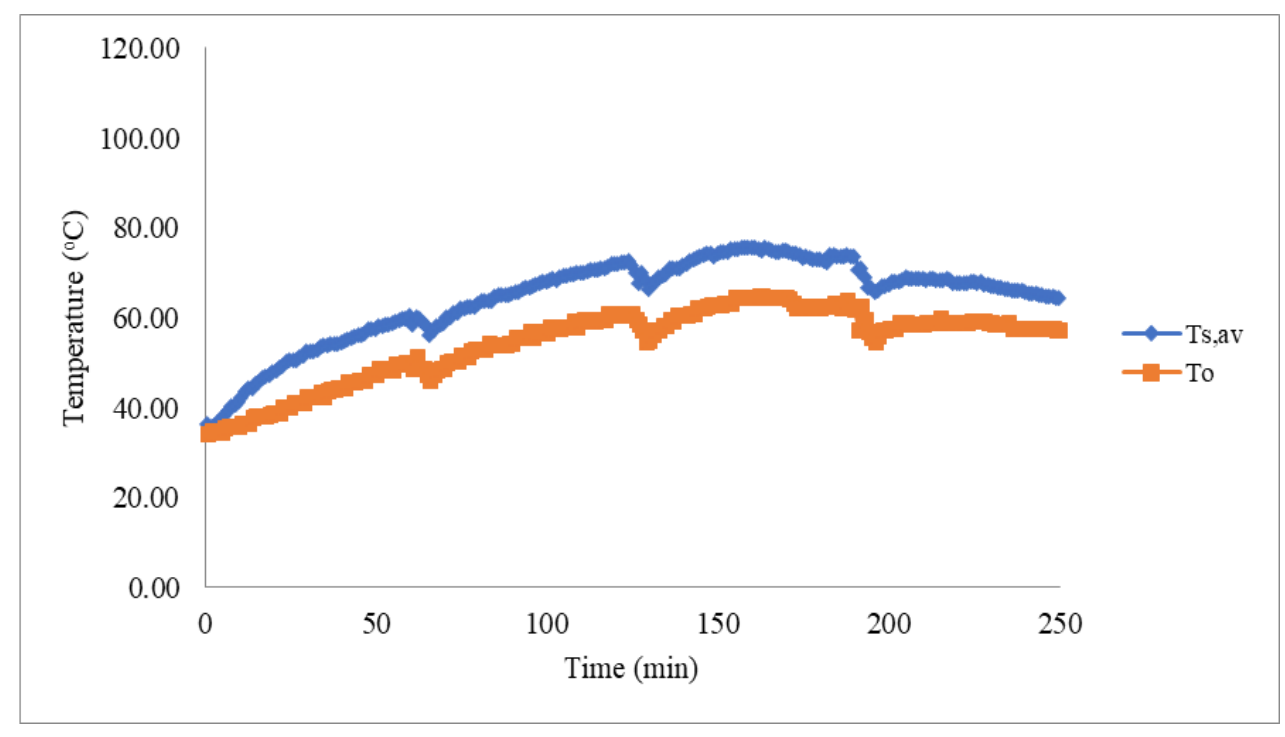

Figure 6 Distribution of average drying temperature and drying chamber outlet temperature In summary, the temperature distribution in this study is shown in Figure 7.

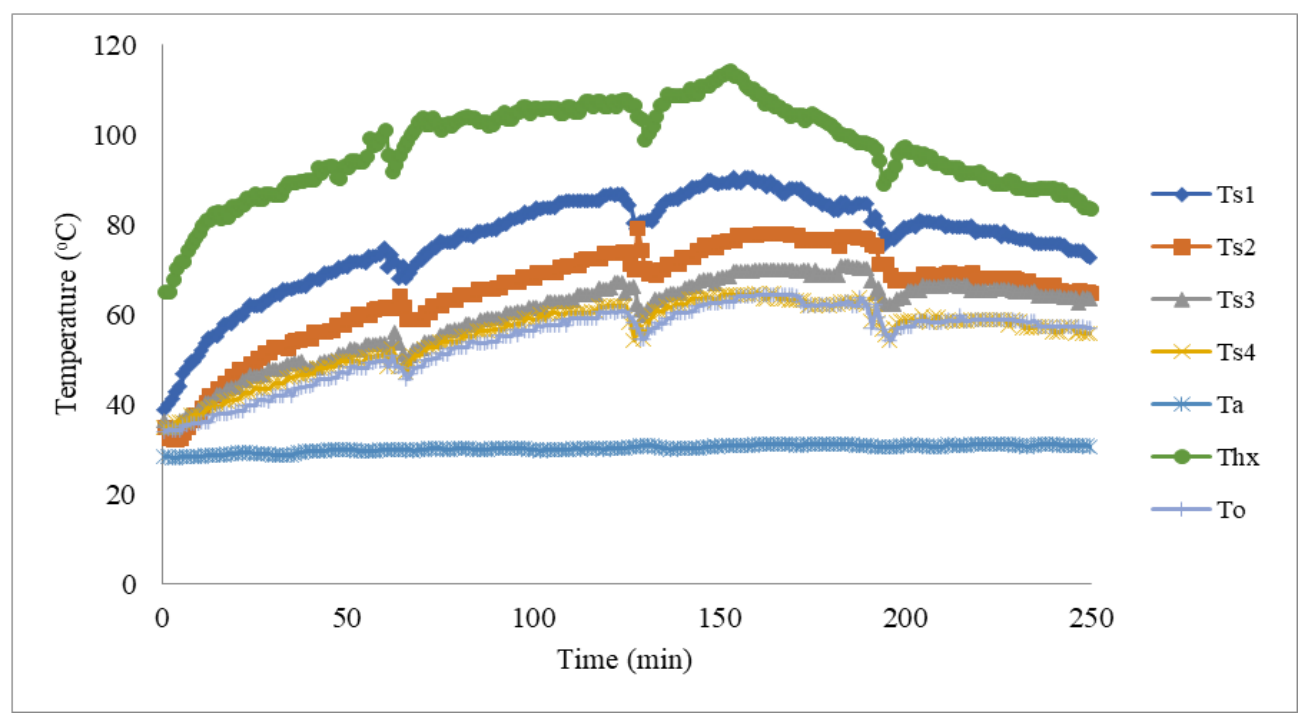

Figure 7 Distribution of drying temperature with rice husk energy source

The temperature phenomenon as shown in Figure 7 is the impact of the absence of adding rice husks to the furnace. The temperature at the beginning of combustion has not shown a significant increase. At this time the rice husk is still in the process of evaporating its moisture content. After the rice husks began to turn into charcoal, the temperature increased significantly. The highest temperature is produced when the rice husk is in the form of charcoal. Rice husks have a moisture content of 10\% [19], so that the rice husks first undergo an evaporation process before further heating occurs [20]. Rice husks which are used as an energy source with a furnace added with a heat exchanger provide a significant 
temperature increase compared to sun drying. This dryer model can be used post-harvest for small farmers in the drying process to replace sun drying.

\section{Conclusion}

The use of a heat exchanger from a black steel pipe that is placed in the furnace and a source of energy from rice husks provide a significant temperature increase. From the results of the thermal evaluation carried out in this study, it was found that the average outlet temperature of the heat exchanger pipe was $97.08^{\circ} \mathrm{C}$ with a range of $65.06-114.32^{\circ} \mathrm{C}$. The hot air produced at this temperature is used for testing drying corn in the drying chamber. The average drying temperature is $64.33^{\circ} \mathrm{C}$ with a range of $35.63-75.68^{\circ} \mathrm{C}$. The remaining hot air after being used for the drying process, namely the air out of the drying room has an average temperature of $54.33^{\circ} \mathrm{C}$ with a range of $34.05-64.53^{\circ} \mathrm{C}$.

\section{Compliance with ethical standards}

\section{Acknowledgments}

The author also wishes to thank the Department of Mechanical Engineering, University of Mataram for facilitating the implementation of this research.

\section{Disclosure of conflict of interest}

The authors declare no conflict of interest.

\section{References}

[1] Incropera FP, DeWitt DP, Bergman T, Lavine A. Fundamental of heat and mass transfer, Sixth edition. John Wiley \& Sons, New York. 2006.

[2] Susana IGB. Improve of worker performance and quality of anchovy with ergonomic hybrid solar dryer. ARPN Journal of Engineering and Applied Sciences. 2018; 13(5): 1662-1667.

[3] Hamdani, Rizal TA, Muhammad Z. Fabrication and testing of hybrid solar-biomass dryer for drying fish. Case Studies in Thermal Engineering. 2018; 12: 489-496.

[4] Alit IB, Susana IGB. Pengaruh kecepatan udara pada alat pengering jagung dengan mekanisme penukar kalor. Rekayasa Mesin. 2020; 11(1): 77-84.

[5] Nguimdo LA, Noumegnie VAK. Design and implementation of an automatic indirect hybrid solar dryer for households and small industries. International Journal of Renewable Energy Research. 2020; 10(3): 1415-1425.

[6] Manaa S, Younsi M, Moummi N. Study of methods for drying dates; review the traditional drying methods in the region of Touat Wilaya of Adrar-Algeria. Energy Procedia. 2013; 36: 521-524.

[7] Ochoa-Martinez CI, Quintero PT, Ayala AA, Ortiz MJ. Drying characteristics of mango slices using the refractance windowtm technique. Journal of Food Engineering. 2012; 109(1): 69-75.

[8] Link JV, Tribuzi G, Laurindo JB. Improving quality of dried fruits: a comparison between conductive multi-flash and traditional drying methods. LWT-Food Science and Technology. 2017; 84: 717-725.

[9] Burhenne L, Messmer J, Aicher T, Laborie MP. The effect of the biomass components lignin, cellulose and hemicellulose on tga and fxed bed pyrolysis. Journal of Analytical and Applied Pyrolysis. 2013; 101: 177-184.

[10] Quispe I, Navia R, Kahhat R. Energy potential from rice husk through direct combustion and fast pyrolysis: a review. Waste Management. 2017; 59: 200-210.

[11] Tangka JK, Ngah JK, Tidze VC, Sako ET. A rice husk fired biomass stove for cooking, water and space heating. International Journal of Trend in Research and Development. 2018; 5(6): 83-89.

[12] Chokphoemphun S, Eiamsa-ard S, Promvonge P. Rice husk combustion characteristics in a rectangular fluidizedbed combustor with triple pairs of chevron-shaped discrete ribbed walls. Case Studies in Thermal Engineering. $2019 ; 14 ; 1-7$.

[13] Alit IB, Susana IGB. Pengering berpenukar kalor dengan sumber energi sekam padi. Machine: Jurnal Teknik Mesin. 2020; 6(2): 1-5. 
[14] Susana IG B, Yudhyadi IGNK, Alit IB, Mirmanto, Okariawan IDK. Effect of hole spacing and number of pipe on dryer box temperature. International Journal of Mechanical Engineering and Technology. 2017; 8(11): 10291035.

[15] RUED Provinsi Nusa Tenggara Barat. Potensi limbah perkebunan untuk biomassa. Peraturan Daerah Provinsi Nusa Tenggara Barat. 2019; 3.

[16] KPMG. Lombok: Prefeasibility Studies on RE Solutions, Januari. 2019.

[17] Mofijur M, Mahlia TMI, Logeswaran J, Anwar M, Silitonga AS, Ashrafur Rahman SM, Shamsuddin AH. Potential of rice industry biomass as a renewable energy source. Energies. 2019; 12(21): 1-21.

[18] Parsonage NG. Thermal conductivity, Chapter 6. The Gaseous State, The Commonwealth and International Library: Chemistry Division. 1966; 83-92.

[19] Herodian S. Peluang dan tantangan industri berbasis hasil samping pengolahan padi. Jurnal Pangan. 2007; 16(1): 38-49.

[20] Mufid F, Anis S. Pengaruh jenis dan ukuran biomassa terhadap proses gasifikasi menggunakan downdraft gasifier. Rekayasa Mesin. 2019; 10(3): 217-226. 